International Journal of Social Science And Human Research

ISSN(print): 2644-0679, ISSN(online): 2644-0695

Volume 05 Issue 02 February 2022

DOI: 10.47191/ijsshr/v5-i2-06, Impact factor-5.586

Page No: 418-425

\title{
A Study of Bullying on Social Media among Senior Secondary School Students With Reference to Gender and Type of School
}

\author{
Dr. Tabassum Fatima ${ }^{1}$, Prof. Mohd Abid Siddiqui ${ }^{2}$ \\ ${ }^{1}$ Post Doctoral Fellow, ICSSR, New Delhi, India \\ ${ }^{2}$ Professor, Department of Education, Aligarh Muslim University, Aligarh, India
}

\begin{abstract}
Bullying on various social media platforms is a new societal issue that has gotten a lot of attention from academics. It has been recognized as a serious health issue among adolescents. Cyber bullying can take many different forms. It doesn't always imply breaking into someone's accounts or pretending to be someone else. It also includes making disparaging remarks about someone or circulating rumors in order to slander them. Because everyone is engrossed in social media, it is quite easy for anyone to abuse their access. The present study is an attempt to analyze various aspects of bullying on social media among senior secondary school students. The study has also taken into consideration the type of school (government and private) and gender variables which was carried out on the sample of 305 senior secondary school adolescents of Aligarh district. The study has revealed mixed results which have been interpreted with some suggestive measures.
\end{abstract}

\section{INTRODUCTION}

Access to the internet is very easy today, and as a result, it is the most common medium for finding information. It also allows individuals to connect to each other even if they are miles apart through various social media platforms like facebook, whatsapp, twitter etc. In recent years, social media have been the prevalent tools for online communication combining the interpersonal and mass communication competences together (Pempek, et al; 2009). It is daily setting new standards for most vital aspects of an adolescents' life such as how they should look, behave or react to a particular situation. During the COVID-19 pandemic, there has been an upsurge in the number of children and teenagers who use digital media. They're not just using digital platforms for personal use; they're also using them for instructional objectives. Students who are bullied are more inclined to cyber bully due to the rising use of smart phones and social media. Hinduja and Patchin (2008) said that Cyber bullying, which occurs in a virtual domain, is a (relatively) new sort of harassment that involves the use of apps designed for the Internet, cellular phones, or other technological platforms that allow for interpersonal communication. They defined cyber bullying as the intentional and repeated harming of others through the use of electronic gadgets. Lefler et al (2014) found that in majority of cases in cyberspace, the identity of the cyber bully was known to the victim. Boys tended to bully more often than did girls. Craig et al (2020) social media usage exposes young people to the risks for involvement in cyber-bullying and to more aggressive online behaviors particularly for boys. The time adolescents spend on social media, engage in problematic use, and talk to strangers online each relate to cyber-bullying and merit public health intervention. Smith et al (2008) found phone and text message bullying to be most prevalent, with girls being ore cyber bullied. Noret and Rivers (2006) reported girls to be more bullied on social media rather than boys. Raskauskas and Stoltz (2007) found that many cyber victims were also traditional victims, and most cyber bullies were also traditional bullies. Maheshwari, R (2020) in her article mentioned that $22.4 \%$ of the 630 teenaged respondents of Delhi region in India who were using internet for more than 3 hours per day were vulnerable to online bullying while who used for more than 4 hour faced cyber bullying. There had been $25 \%$ increase in cases from 2017 to 2018 as per the National crime records bureau. However in an online survey done in 28 countries regarding the awareness of cyber bullying only $63 \%$ Indians replied in positive claiming the $22^{\text {nd }}$ position among all. (Joseph,J. statisa.com,2018). The present study is thus an endeavor to study the bullying on social media among senior secondary school students with reference to gender and type of school.

\section{OBJECTIVES}

1. To find out the significant difference in bullying on social media w.r.t gender and type of school.

2. To explore the levels of bullying on social media among total sample, male- female sample, government and private school sample

3. To explore the time spent daily on social media by total sample, male-female sample, government and private school sample 


\section{A Study of Bullying on Social Media among Senior Secondary School Students With Reference to Gender and Type of School}

4. To analyze the significant aspect of bullying behavior on social media among senior secondary students.

\section{Hypothesis:}

Ho1: There would be no significant difference bullying on social media w.r.t gender and type of school.

\section{Research Questions:}

2. What will be the relative percentages in regard to levels of bullying on social media among total sample, male- female sample, government and private school sample?

3. What will be the relative percentage of the amount of time spent daily on social media by total sample, male- female sample, government and private school sample?

4.1 What will be the relative percentage of students who faced cyber mobbing while sharing their views on social media?

4.2 What will be the relative percentages of students who get conscious of their appearance due to online mocking of their pictures posted on social media?

4.3 What will be the relative percentages of students who post filtered and edited pictures on social media to avoid nasty comments from their friends?

4.4 What will be the relative percentages of students who have been forced to chat and share intimate details and pictures on social media?

4.5 What will be the relative percentages of students whose friends use abusive and insulting language while messaging them?

4.6 What will be the relative percentages of students who have used online social groups for personal gains by spreading rumors about someone in school groups?

4.7 What will be the relative percentages of students who have sent nasty comments and emailed spam messages to others?

4.8 What will be the relative percentages of students who have made somebody's pictures viral on the social media without their consent?

4.9 What will be the relative percentages of students who have used pictures of their friends to make fake social media accounts?

\section{METHODOLOGY AND DESIGN OF STUDY}

In the present study the target population was the senior secondary school students studying in government and private schools of Aligarh District. A total of 305 senior secondary school students were randomly selected as sample from which 141 were male students and 164 were female students while 143 were from government schools and 162 were from private schools. A self made questionnaire with twelve questions was used where 5 questions were asked to know the percentage of students who were being bullied and 4 negative questions were asked to know percentage involved in bullying.

\section{ANALYSIS AND INTERPRETATION}

The collected data for the present research was analyzed by the application of statistical techniques keeping in view the objectives of study. Analysis was done using the SPSS software. $t$ test and percentage analysis were the major techniques used by researcher. The obtained results are being presented as per the hypothesis and research questions framed for achieving the objectives, results of which are presented below.

Table 1: Comparison of means scores of bullying on social media with respect to gender and type of school

\begin{tabular}{|l|l|l|l|l|l|l|l|}
\hline Sample & Groups & N & Mean & SD & df & 't' value & Remark \\
\hline \multirow{3}{*}{$\begin{array}{l}\text { Bullying on } \\
\text { Social Media }\end{array}$} & Male & 141 & 35.30 & 11.61 & & $2.438^{*}$ & Significant at 0.05 \\
\cline { 2 - 5 } & Female & 164 & 31.86 & 12.86 & \multirow{3}{*}{303} & & \\
\cline { 2 - 5 } & $\begin{array}{l}\text { Government } \\
\text { School }\end{array}$ & 143 & 31.76 & 11.93 & & $2.261^{*}$ & Significant at 0.05 \\
\cline { 2 - 5 } & Private School & 162 & 34.95 & 12.64 & & & \\
\hline
\end{tabular}

When the mean scores of bullying on social media were compared for male and female senior secondary school students the $t$ value came out to be 2.438 showing significant difference between these compared groups at 0.05 level of confidence. Based on the mean values it can be said that male students overall were bullied more on social media than the female counterparts. Similarly the table 


\section{A Study of Bullying on Social Media among Senior Secondary School Students With Reference to Gender and Type of School}

also shows significant difference between students of government and private schools in regard to the social media bullying. The private school students faced more online bullying rather than students of government schools. Ho1 is thus rejected.

Table 2. Percentage of levels of bullying on social media among total sample groups

\begin{tabular}{|c|c|c|c|c|c|c|c|c|c|c|}
\hline & \multicolumn{2}{|c|}{$\begin{array}{l}\text { Total Sample } \\
\text { (305) }\end{array}$} & \multicolumn{2}{|c|}{$\begin{array}{ll}\text { Total } & \text { Male } \\
\text { Sample } & \\
(141) & \end{array}$} & \multicolumn{2}{|c|}{$\begin{array}{ll}\text { Total } & \text { Female } \\
\text { Sample } & \\
(164) & \end{array}$} & \multicolumn{2}{|c|}{$\begin{array}{l}\text { Total } \\
\text { Government } \\
\text { Sample } \\
\text { (143) }\end{array}$} & \multicolumn{2}{|c|}{$\begin{array}{l}\text { Total } \\
\text { Sample } \\
(162)\end{array}$} \\
\hline & $\mathbf{N}$ & $\%$ & $\mathbf{N}$ & $\%$ & $\mathbf{N}$ & $\%$ & $\mathbf{N}$ & $\%$ & $\mathbf{N}$ & $\%$ \\
\hline High Bullying & 52 & 17.049 & 23 & 16.31 & 27 & 16.46 & 24 & 16.78 & 23 & 14.19 \\
\hline Average Bullying & 214 & 70.16 & 93 & 65.95 & 126 & 76.82 & 94 & 65.73 & 126 & 77.7 \\
\hline Low Bullying & 39 & 12.62 & 25 & 17.73 & 11 & 6.707 & 25 & 17.48 & 13 & 8.02 \\
\hline
\end{tabular}

It is evident from the above table 2 that out of the total sample of 305 senior secondary students $17.049 \%$ faced high bullying, $70.16 \%$ suffered with average bullying while $12.62 \%$ came across low bullying. In case of male sample $16.31 \%(23)$ students were found to suffer from high bullying, $65.95 \%$ with average bullying and rest $17.73 \%$ students were the ones who faced it with low intensity. Similarly, $16.46 \%$ female senior secondary students were survivors of high bullying, while only $6.07 \%$ faced low bullying. Among the students studying in government and private school $16.78 \%$ and $14.19 \%$ faced high bullying while $17.48 \%$ and $8.02 \%$ were subjected to low bullying respectively. The results overall indicates that female students and students of private school are more exposed to online bullying.

Table 3. Percentage of amount of time spent daily on social media

\begin{tabular}{|c|c|c|c|c|c|c|c|c|c|c|}
\hline & \multicolumn{2}{|c|}{$\begin{array}{l}\text { Total Sample } \\
\text { (305) }\end{array}$} & \multicolumn{2}{|c|}{$\begin{array}{ll}\text { Total } & \text { Male } \\
\text { Sample } & \\
(141) & \\
\end{array}$} & \multicolumn{2}{|c|}{$\begin{array}{ll}\text { Total Female } \\
\text { Sample } \\
(164)\end{array}$} & \multicolumn{2}{|c|}{$\begin{array}{l}\text { Total } \\
\text { Government } \\
\text { Sample }(143)\end{array}$} & \multicolumn{2}{|c|}{$\begin{array}{ll}\text { Total Private } \\
\text { Sample } \\
(162)\end{array}$} \\
\hline & $\mathbf{N}$ & $\%$ & $\mathbf{N}$ & $\%$ & $\mathbf{N}$ & $\%$ & $\mathbf{N}$ & $\%$ & $\mathbf{N}$ & $\%$ \\
\hline $1 \mathrm{hr}$ & 157 & 51.47 & 79 & 56.02 & 78 & 47.56 & 81 & 56.64 & 76 & 46.91 \\
\hline $2-4 \mathrm{hr}$ & 124 & 40.65 & 50 & 35.46 & 74 & 45.12 & 49 & 34.26 & 75 & 46.29 \\
\hline More than $6 \mathrm{hrs}$ & 24 & 7.86 & 12 & 8.51 & 12 & 7.31 & 13 & 9.09 & 11 & 6.79 \\
\hline
\end{tabular}

157 students $(51.47 \%)$ from the total sample use social media for one hour daily while $7.86 \%$ spend more than 6 hours. $8.51 \%$ of the male sample used social media for more than 6 hours daily while $56.02 \%$ used it at least for one hour. 47.565 female used different social media for one hour daily, $45.12 \%$ spent 2 to 4 hrs while only $7.31 \%$ spent more than 6 hours on social media platforms. 56.64\% Government school students gave 1 hour daily to social media as compared to private school students where only $46.91 \%$ used it for an hour. Approximately 34\% government school adolescents were found to use social media for 2 to 4 hours as compared to $46.29 \%$ private school children. Also it was observed that more percentage of government school students (9.09\%) spent more than $6 \mathrm{hrs}$ on social media wr.t private school sample $(6.79 \%)$. It can thus be clearly said that it is more of the private school students spending time on social media rather than the government school students.

Table 4.1: Percentage of students faced cyber mobbing while sharing their views on social media

\begin{tabular}{|c|c|c|c|c|c|c|c|c|c|c|}
\hline & \multicolumn{2}{|c|}{$\begin{array}{l}\text { Total Sample } \\
(305)\end{array}$} & \multicolumn{2}{|c|}{$\begin{array}{l}\text { Total } \quad \text { Male } \\
\text { Sample } \\
(141)\end{array}$} & \multicolumn{2}{|c|}{$\begin{array}{l}\text { Total Female } \\
\text { Sample } \\
(164)\end{array}$} & \multicolumn{2}{|c|}{$\begin{array}{l}\text { Total } \\
\text { Government } \\
\text { Sample } \\
(143) \\
\end{array}$} & \multicolumn{2}{|c|}{$\begin{array}{l}\text { Total Private } \\
\text { Sample } \\
(162)\end{array}$} \\
\hline & $\mathbf{N}$ & $\%$ & $\mathbf{N}$ & $\%$ & $\mathbf{N}$ & $\%$ & $\mathbf{N}$ & $\%$ & $\mathbf{N}$ & $\%$ \\
\hline Often & 3 & 0.98 & 3 & 2.13 & $\mathbf{0}$ & 0.00 & 3 & 2.10 & $\mathbf{0}$ & 0.00 \\
\hline Sometimes & 37 & 12.13 & 24 & 17.02 & 13 & 7.93 & 22 & 15.38 & 15 & 9.26 \\
\hline Rarely & 24 & 7.87 & 6 & 4.26 & 18 & 10.97 & 9 & 6.29 & 15 & 9.26 \\
\hline Never & 241 & 79.02 & 108 & 76.60 & 133 & 81.90 & 109 & 76.22 & 132 & 81.48 \\
\hline
\end{tabular}




\section{A Study of Bullying on Social Media among Senior Secondary School Students With Reference to Gender and Type of School}

Cyber mobbing happens when a person tries to express his views but is ganged by others and bullied. In the present study, out of the total sample of 305 students 64 (20.98\%) have faced cyber mobbing leaving $79.02 \%$ who blissfully never came across it as shown in table 4.1. Male students (23.4\%) have been more cyber mobbed as compared to their female counterparts where only $18.1 \%$ have experienced it. Among the students of government schools $76.22 \%$ replied that they have never faced such a thing while $23.78 \%$ have sometime during their usage have been mobbed. Further, $81.48 \%$ senior secondary students of private schools were never ambushed on social media but $18.52 \%$ share their experience of it. It becomes evident from the responses presented in the above table that cyber mobbing is faced by about $20 \%$ population of our students. It indicates that cyber mobbing is an issue and it is hurting the psychological sentiments of young students in expressing their views in democratic set up. It has its negative consequences in their other aspects of life as well as achievement in the field of education.

Table 4.2: Percentage of students getting conscious of appearance due to online mocking of their pictures

\begin{tabular}{|c|c|c|c|c|c|c|c|c|c|c|}
\hline & \multicolumn{2}{|c|}{$\begin{array}{l}\text { Total Sample } \\
(305)\end{array}$} & \multicolumn{2}{|c|}{$\begin{array}{l}\text { Total } \quad \text { Male } \\
\text { Sample } \\
(141)\end{array}$} & \multicolumn{2}{|c|}{$\begin{array}{l}\text { Total Female } \\
\text { Sample } \\
(164)\end{array}$} & \multicolumn{2}{|c|}{$\begin{array}{l}\text { Total } \\
\text { Government } \\
\text { Sample } \\
(143) \\
\end{array}$} & \multicolumn{2}{|c|}{$\begin{array}{ll}\text { Total Private } \\
\text { Sample } \\
(162)\end{array}$} \\
\hline & $\mathbf{N}$ & $\%$ & $\mathbf{N}$ & $\%$ & $\mathbf{N}$ & $\%$ & $\mathbf{N}$ & $\%$ & $\mathbf{N}$ & $\%$ \\
\hline Often & 70 & 22.95 & 64 & 45.39 & 6 & 3.66 & 4 & 2.80 & 66 & 40.74 \\
\hline Sometimes & 31 & 10.16 & 11 & 7.80 & 20 & 12.20 & 11 & 7.69 & 20 & 12.35 \\
\hline Rarely & 31 & 10.16 & 11 & 7.80 & 20 & 12.20 & 15 & 10.49 & 16 & 9.88 \\
\hline Never & 173 & 56.72 & 55 & 39.01 & 118 & 71.95 & 113 & 79.02 & 60 & 37.04 \\
\hline
\end{tabular}

Adolescence is the age where adolescents are very conscious of their appearance. $22.95 \%$ adolescents said they are often mocked for their appearance on social media which makes them conscious about their appearance. 20.32\% have been mocked sometime or the other while $56.72 \%$ have never faced such criticism. Further, $39.01 \%$ boys and $71.95 \%$ girls said they never got mocked for their appearance which would make them conscious. However, shockingly $45.39 \%$ boys are often poked for fun about their appearance and only $3.66 \%$ females often face it. $62.96 \%$ of students going to private school said they have been made conscious of their appearance on different social media platforms while only $20.98 \%$ government school students have come across online body shaming. It is clear that about $43 \%$ of the adolescents are made conscious of their appearance by their age mates in some way or the other. This body shaming can have long term consequences especially mental health. It could lead to low self esteem with depressive symptoms. This is worth the attention as it may lead to dislike the schools by victims thus increase in absenteeism and under achievement.

Table 4.3: Percentage of students posting filtered and edited pictures to avoid nasty comments

\begin{tabular}{|c|c|c|c|c|c|c|c|c|c|c|}
\hline & \multicolumn{2}{|c|}{$\begin{array}{l}\text { Total Sample } \\
\text { (305) }\end{array}$} & \multicolumn{2}{|c|}{$\begin{array}{ll}\text { Total } & \text { Male } \\
\text { Sample } & \\
(141) & \end{array}$} & \multicolumn{2}{|c|}{$\begin{array}{ll}\text { Total } & \text { Female } \\
\text { Sample } & \\
(164) & \end{array}$} & \multicolumn{2}{|c|}{$\begin{array}{l}\text { Total } \\
\text { Government } \\
\text { Sample } \\
(143)\end{array}$} & \multicolumn{2}{|c|}{$\begin{array}{ll}\text { Total Private } \\
\text { Sample } \\
(162)\end{array}$} \\
\hline & $\mathbf{N}$ & $\%$ & $\mathbf{N}$ & $\%$ & $\mathbf{N}$ & $\%$ & $\mathbf{N}$ & $\%$ & $\mathbf{N}$ & $\%$ \\
\hline Often & 17 & 5.57 & 8 & 5.67 & 9 & 5.49 & 4 & 2.80 & 1 & 8.02 \\
\hline Sometimes & 40 & 13.11 & 14 & 9.93 & 26 & 15.85 & 22 & 15.38 & 18 & 11.11 \\
\hline Rarely & 34 & 11.15 & 19 & 13.48 & 15 & 9.15 & 22 & 15.38 & 12 & 7.41 \\
\hline Never & 214 & 70.16 & 100 & 70.92 & 114 & 69.51 & 95 & 66.43 & 119 & 73.46 \\
\hline
\end{tabular}

A glance on the table 4.3 shows that $70.16 \%$ senior secondary adolescents have never posted filtered or edited pictures of themselves online while remaining $29.84 \%$ have done it some or the other time to avoid nasty comments of their peers. $29.08 \%$ males and $30.49 \%$ females too have used filtered pictures to avoid being made fun of. Further, as $66.43 \%$ government school students and $73.46 \%$ private school students have never used edited pictures implies that it were more of the government school going students with $33.57 \%$ who use edited pictures as compared to only $26.54 \%$ of private schools.

Tormented by the body shaming of any form, $30 \%$ of the adolescent population is left with no choice than to modify their pictures before posting it online. This diehard need to be liked by their social groups and gathering maximum likes without getting trolled 


\section{A Study of Bullying on Social Media among Senior Secondary School Students With Reference to Gender and Type of School}

has increased the use of filter apps by manifolds thus making it difficult for a teenager to accept himself as they way he is causing a huge negative impact on the self esteem.

Table 4.4: Percentage of students forced to chat and share intimate details and pictures on social media

\begin{tabular}{|c|c|c|c|c|c|c|c|c|c|c|}
\hline & \multicolumn{2}{|c|}{$\begin{array}{l}\text { Total Sample } \\
\text { (305) }\end{array}$} & \multicolumn{2}{|c|}{$\begin{array}{l}\text { Total } \quad \text { Male } \\
\text { Sample } \\
(141)\end{array}$} & \multicolumn{2}{|c|}{$\begin{array}{l}\text { Total Female } \\
\text { Sample } \\
(164)\end{array}$} & \multicolumn{2}{|c|}{$\begin{array}{l}\text { Total } \\
\text { Government } \\
\text { Sample } \\
(143) \\
\end{array}$} & \multicolumn{2}{|c|}{$\begin{array}{ll}\text { Total Private } \\
\text { Sample } \\
(162)\end{array}$} \\
\hline & $\mathbf{N}$ & $\%$ & $\mathbf{N}$ & $\%$ & $\mathbf{N}$ & $\%$ & $\mathbf{N}$ & $\%$ & $\mathbf{N}$ & $\%$ \\
\hline Often & 78 & 25.57 & 17 & 12.06 & 61 & 37.20 & 36 & 25.17 & 42 & 25.93 \\
\hline Sometimes & 24 & 7.87 & 7 & 4.96 & 17 & 10.37 & 18 & 12.59 & 6 & 3.70 \\
\hline Rarely & 10 & 3.28 & 6 & 4.26 & 4 & 2.44 & 8 & 5.59 & 2 & 1.23 \\
\hline Never & 193 & 63.28 & 111 & 78.72 & 82 & 50.00 & 81 & 56.64 & 112 & 69.14 \\
\hline
\end{tabular}

Table 4.4 shows that tragically $36.72 \%$ adolescents have been forced to chat, share intimate details or nudes on social media. More harrowing is the fact that $12.06 \%$ males and $37.20 \%$ female sample said they often come across this demand. Overall $50 \%$ females have been forced to give intimate details while $50 \%$ of them never received such kinds of messages. Further, 56.64\% government school pupils and $69.14 \%$ private school pupils never came across such debauch behavior, which in turn implies that government school students faced more than the private school children with $43.36 \%$ and $30.86 \%$ respectively. Forcing anybody specially adolescents to chat intimately has grown widely over years and researches have shown to have negative effect it causes on the sexual as well as the mental development of students. The present study has revealed $36 \%$ adolescents to have fallen prey to this. It is important for adults and educators to know the relationship of it with mental health and its effect on studies so as to plan appropriate strategies to combat it.

Table 4.5: Percentage of students getting messages from friends using abusive and insulting language

\begin{tabular}{|c|c|c|c|c|c|c|c|c|c|c|}
\hline & \multicolumn{2}{|c|}{$\begin{array}{l}\text { Total Sample } \\
\text { (305) }\end{array}$} & \multicolumn{2}{|c|}{$\begin{array}{ll}\text { Total } & \text { Male } \\
\text { Sample } & \\
(141) & \end{array}$} & \multicolumn{2}{|c|}{$\begin{array}{l}\text { Total Female } \\
\text { Sample } \\
(164)\end{array}$} & \multicolumn{2}{|c|}{$\begin{array}{l}\text { Total } \\
\text { Government } \\
\text { Sample } \\
(143)\end{array}$} & \multicolumn{2}{|c|}{$\begin{array}{l}\text { Total Private } \\
\text { Sample } \\
(162)\end{array}$} \\
\hline & $\mathbf{N}$ & $\%$ & $\mathbf{N}$ & $\%$ & $\mathbf{N}$ & $\%$ & $\mathbf{N}$ & $\%$ & $\mathbf{N}$ & $\%$ \\
\hline Often & 34 & 11.15 & 21 & 14.89 & 13 & 7.93 & 8 & 5.59 & 26 & 16.05 \\
\hline Sometimes & 41 & 13.44 & 20 & 14.18 & 21 & 12.80 & 36 & 25.17 & 5 & 3.09 \\
\hline Rarely & 44 & 14.43 & 19 & 13.48 & 25 & 15.24 & 20 & 13.99 & 24 & 14.81 \\
\hline Never & 186 & 60.98 & 81 & 57.45 & 105 & 64.02 & 79 & 55.24 & 107 & 66.05 \\
\hline
\end{tabular}

Perusal of table 4.5 shows that $11.15 \%$ adolescents often come across the abusive and insulting language from their friends while messages. Friends of $27.87 \%$ students sometimes use abusive language to them on texts while $60.98 \%$ have never faced such issue from their friends. $57.45 \%$ male students too have never got such messages from their friends but $42.55 \%$ boys agreed to the fact of being called upon with verbal and abusive words from their friends. $35.98 \%$ females have also ticked to the facet that their peers use abusive and insulting language while messaging to them. 55.24\% government school going students and $66.05 \%$ private school students has never got text where abusive words were used for them. However, $16.05 \%$ students of private school and $5.59 \%$ of government school students were bullied from their friends who often sent insulting messages on social media.

Table 4.6: Percentage of students using online social groups for personal benefit by spreading rumors about someone

\begin{tabular}{|c|c|c|c|c|c|c|c|c|c|c|}
\hline & \multicolumn{2}{|c|}{$\begin{array}{l}\text { Total Sample } \\
\text { (305) }\end{array}$} & \multicolumn{2}{|c|}{$\begin{array}{ll}\text { Total } & \text { Male } \\
\text { Sample } & \\
(141) & \end{array}$} & \multicolumn{2}{|c|}{$\begin{array}{l}\text { Total Female } \\
\text { Sample } \\
(164)\end{array}$} & \multicolumn{2}{|c|}{$\begin{array}{l}\text { Total } \\
\text { Government } \\
\text { Sample } \\
(143)\end{array}$} & \multicolumn{2}{|c|}{$\begin{array}{ll}\text { Total Private } \\
\text { Sample } \\
(162)\end{array}$} \\
\hline & $\mathbf{N}$ & $\%$ & $\mathbf{N}$ & $\%$ & $\mathbf{N}$ & $\%$ & $\mathbf{N}$ & $\%$ & $\mathbf{N}$ & $\%$ \\
\hline Often & 19 & 6.22 & 6 & 4.26 & 13 & 7.93 & 4 & 2.80 & 15 & 9.26 \\
\hline Sometimes & 37 & 12.13 & 20 & 14.1 & 17 & 10.37 & 28 & 19.58 & 9 & 5.56 \\
\hline Rarely & 51 & 16.72 & 26 & 18.43 & 25 & 15.24 & 24 & 16.78 & 27 & 16.67 \\
\hline Never & 198 & 64.91 & 89 & 63.12 & 109 & 66.46 & 87 & 60.83 & 111 & 68.52 \\
\hline
\end{tabular}




\section{A Study of Bullying on Social Media among Senior Secondary School Students With Reference to Gender and Type of School}

Perusal of table 4.6 shows that $64.91 \%$ of the total sample never used the social media to spread rumors about anybody for personal benefit. However, $35.09 \%$ adolescents have at some instances used for spreading fake rumors which create a matter of concern. Further $63.12 \%$ males and $66.46 \%$ females although never used social media to indulge in online rumoring but it is alarming to see $36.88 \%$ male students and $33.54 \%$ female students using the online social groups to tarnish somebody's image to personal advantage. $60.83 \%$ students going to government schools never spread any online rumor, yet $39.17 \%$ did use online rumoring for personal interest which is more than those of the private school students where $31.48 \%$ have done the same sometime or the other. Spreading of fake news about someone has an adverse impact on the individual by exacerbating their friend circle and image by causing mistrust. It creates unrealistic views about other's lives and increase peer pressure. It is necessary to make $35 \%$ students involved in this act aware of the harmful psychological and academic effects it causes on the lives of students falling prey to it.

Table 4.7: Percentage of students who have emailed nasty comments and spam messages to others

\begin{tabular}{|c|c|c|c|c|c|c|c|c|c|c|}
\hline & \multicolumn{2}{|c|}{$\begin{array}{l}\text { Total Sample } \\
(305)\end{array}$} & \multicolumn{2}{|c|}{$\begin{array}{l}\text { Total } \quad \text { Male } \\
\text { Sample } \\
(141)\end{array}$} & \multicolumn{2}{|c|}{$\begin{array}{ll}\text { Total } & \text { Female } \\
\text { Sample } & \\
(164) & \end{array}$} & \multicolumn{2}{|c|}{$\begin{array}{l}\text { Total } \\
\text { Government } \\
\text { Sample } \\
(143)\end{array}$} & \multicolumn{2}{|c|}{$\begin{array}{ll}\text { Total } & \text { Private } \\
\text { Sample } & \\
(162) & \end{array}$} \\
\hline & $\mathbf{N}$ & $\%$ & $\mathbf{N}$ & $\%$ & $\mathbf{N}$ & $\%$ & $\mathbf{N}$ & $\%$ & $\mathbf{N}$ & $\%$ \\
\hline Often & 41 & 13.4 & 22 & 15.60 & 19 & 11.59 & 5 & 3.50 & 36 & 22.22 \\
\hline Sometimes & 51 & 16.7 & 40 & 28.37 & 11 & 6.71 & 29 & 20.28 & 22 & 13.58 \\
\hline Rarely & 54 & 17.7 & 34 & 24.11 & 20 & 12.20 & 16 & 11.19 & 38 & 23.46 \\
\hline Never & 159 & 52.1 & 45 & 31.91 & 114 & 69.51 & 91 & 63.64 & 66 & 40.74 \\
\hline
\end{tabular}

Table 4.7 reveals that $52.1 \%$ have never sent nasty emails and messages to others, as compared to $13.4 \%$ who often spam other's mail boxes and $34.4 \%$ who have sometime or the other done that. Further, it were males who are more involved in sending nasty emails with $68.09 \%$ while $30.49 \%$ females who send spam mails and messages. $59.26 \%$ Private school students were found to be sending more of such spam mails as compared to government school students where $37.97 \%$ have done such comments and messages.

Table 4.8: Percentage of students who have made somebody's Pictures viral on social media accounts without consent

\begin{tabular}{|c|c|c|c|c|c|c|c|c|c|c|}
\hline & \multicolumn{2}{|c|}{$\begin{array}{l}\text { Total Sample } \\
\text { (305) }\end{array}$} & \multicolumn{2}{|c|}{$\begin{array}{l}\text { Total } \quad \text { Male } \\
\text { Sample } \\
(141)\end{array}$} & \multicolumn{2}{|c|}{$\begin{array}{l}\text { Total Female } \\
\text { Sample } \\
(164)\end{array}$} & \multicolumn{2}{|c|}{$\begin{array}{l}\text { Total } \\
\text { Government } \\
\text { Sample } \\
(143)\end{array}$} & \multicolumn{2}{|c|}{$\begin{array}{ll}\text { Total Private } \\
\text { Sample } \\
(162)\end{array}$} \\
\hline & $\mathbf{N}$ & $\%$ & $\mathbf{N}$ & $\%$ & $\mathbf{N}$ & $\%$ & $\mathbf{N}$ & $\%$ & $\mathbf{N}$ & $\%$ \\
\hline Often & 14 & 4.59 & 8 & 5.67 & 6 & 3.66 & 7 & 4.90 & 7 & 4.32 \\
\hline Sometimes & 24 & 7.87 & 20 & 14.18 & 4 & 2.44 & 8 & 5.59 & 16 & 9.88 \\
\hline Rarely & 21 & 6.89 & 10 & 7.09 & 11 & 6.71 & 12 & 8.39 & 9 & 5.56 \\
\hline Never & 246 & 80.66 & 103 & 73.05 & 143 & 87.20 & 116 & 81.12 & 130 & 80.25 \\
\hline
\end{tabular}

Table 4.8 reveals that $80.66 \%$ pupils have never made pictures of anybody viral without consent as shown in table $4.8 .4 .59 \%$ do it often and rest $14.76 \%$ have done at some point during social media usage. $73.05 \%$ boys and $87.20 \%$ girls have never done such an act, but matter of concern is that $26.5 \%$ boys have made the pictures viral without the consent as compared to $12.8 \%$ female students. The students from both government and private the schools have acted similarly where $81.12 \%$ and $80.25 \%$ have never shared or forwarded any picture on social media accounts without permission. It is evident that nearly $20 \%$ share the pictures of others without their consent. What starts as fun among friends at times changes to some serious acts where strangers misuse the info by morphing it and forwarding it further to bigger cyber groups leading to serious crimes or ending up as revenge post open for trolling. This causes huge mental agony on the sufferer which can be a lifelong trauma. 


\section{A Study of Bullying on Social Media among Senior Secondary School Students With Reference to Gender and Type of School}

Table 4.9: Percentage of students who have used pictures of friends to make a fake social media account

\begin{tabular}{|c|c|c|c|c|c|c|c|c|c|c|}
\hline & \multicolumn{2}{|c|}{$\begin{array}{l}\text { Total Sample } \\
\text { (305) }\end{array}$} & \multicolumn{2}{|c|}{$\begin{array}{ll}\text { Total } & \text { Male } \\
\text { Sample } & \\
(141) & \end{array}$} & \multicolumn{2}{|c|}{$\begin{array}{ll}\text { Total Female } \\
\text { Sample } \\
(164)\end{array}$} & \multicolumn{2}{|c|}{$\begin{array}{l}\text { Total } \\
\text { Government } \\
\text { Sample } \\
(143) \\
\end{array}$} & \multicolumn{2}{|c|}{$\begin{array}{ll}\text { Total } & \text { Private } \\
\text { Sample } & \\
(162) & \end{array}$} \\
\hline & $\mathbf{N}$ & $\%$ & $\mathbf{N}$ & $\%$ & $\mathbf{N}$ & $\%$ & $\mathbf{N}$ & $\%$ & $\mathbf{N}$ & $\%$ \\
\hline Often & 14 & 4.59 & 6 & 4.26 & 8 & 4.88 & 4 & 2.80 & 10 & 6.17 \\
\hline Sometimes & 37 & 12.13 & 25 & 17.73 & 12 & 7.32 & 28 & 19.58 & 9 & 5.56 \\
\hline Rarely & 41 & 13.44 & 17 & 12.06 & 24 & 14.63 & 20 & 13.99 & 21 & 12.96 \\
\hline Never & 213 & 69.84 & 93 & 65.96 & 120 & 73.17 & 91 & 63.64 & 122 & 75.31 \\
\hline
\end{tabular}

Table 4.9 reveals that $30.16 \%$ of the sample has created fake social media accounts by using the pictures of their friends, while $69.84 \%$ have never done so. Further $34.04 \%$ male students and $26.83 \%$ female students have been involved at some point in using the identity of their friends to create a fake account on social media. Although $63.64 \%$ government school students have never made a fake account with some one's pictures but $36.36 \%$ have created such fake profiles. Similarly $75.31 \%$ private senior secondary school students were never in creating fake profiles. $6.17 \%$ were observed to do it often while $18.52 \%$ have sometime done it. Creating fake social accounts gives a mental shortcut to make room for error and freedom to reveal private info about others. Mostly such accounts are made as part of revenge, ridiculing the weaker ones or spreading rumors by using their personal information and pictures. The present study has shown $30 \%$ of the adolescents carrying out the act which comes under harassment and cases a great distress to the victims. This distress further affects the potential of the student in major way.

\section{CONCLUSION AND SUGGESTIONS}

Bullying on social media has become a common phenomenon with smart phones in hands of every second adolescent. Present study shows that male students and the private school students are more prone to bullying on the social media as compared to their counter parts. Further it was observed that female students and students of private schools are more exposed to average and high bullying rather than male students and government school students respectively. It was also seen that more percentage of government school students that spent more than 6 hrs on social media w.r.t private school sample. Results also revealed that $20.98 \%$ students have faced cyber mobbing-males more than females. $22.95 \%$ students said they get conscious of their appearance due to fun made of their pictures on social media. $45.39 \%$ boys are often poked for fun about their appearance and only $3.66 \%$ females often face it. Due to this $29.8 \%$ students agreed to use filters and editing tools to modify their pictures before posting it online on their social handles.

It was also seen that tragically $36.72 \%$ adolescents have been forced to chat, share intimate details or nudes on social media. Painfully, $12.06 \%$ males and $37.20 \%$ female sample said they often come across this demand. Government school students face this issue than private school students. $11.15 \%$ of the sample is often bullied by their friends in terms of getting abusive and insulting messages from their peers. $42.55 \%$ males and $35.98 \%$ females have received rude messages addressed to them. $64.91 \%$ of the senior secondary school students sample has at some instances used the social media to spread rumors about others for personal benefit. Students of the private school and male students were found to be sending more of the spam mails and messages to others with $59.26 \%$ and $68.09 \%$ than their counterparts.

\section{Suggestions:}

1. Students should be made acquaint with social media for using it for educational purpose.

2. Schools must hold sessions on cyber bullying addressed by technical experts who could educate all on the pros and cons, usage and privacy control methods.

3. Users of social media should be taught to keep password and all personal information safe from prying eyes.

4. Adolescents should Google themselves every now and then to see if any personal information or photographs show up. If something is visible, it should be taken down.

5. Parents should learn to operate various social apps and monitor their ward's behavior to catch unexplained behavioral changes and the potential bully in their profiles.

6. Awareness should be raised regarding various Anti bullying helpline numbers and cyber crime cell where bullying incidences can be reported.

7. Counselling should be done to the students who have become conscious due to constant bullying and also to those who are identified as the bully. They should be made to realize that such things should not be taken seriously as it is not in their hands and it should not disturb their psychological set up. 


\section{A Study of Bullying on Social Media among Senior Secondary School Students With Reference to Gender and Type of School}

\section{ACKNOWLEDGEMENT}

The work described in this paper is financially supported by Indian Council of Social Science Research (ICSSR), New Delhi, India as the part of Post Doctoral Fellowship.

\section{REFERENCES}

1) Craig, W., Boniel-Nissim, M., King, N., Walsh, S., Boer, M., \& Donnelly, P. et al. (2020). Social Media Use and CyberBullying: A Cross-National Analysis of Young People in 42 Countries. Journal Of Adolescent Health, 66(6), S100-S108. doi: 10.1016/j.jadohealth.2020.03.006

2) Hinduja, S., \& Patchin, J. W. (2008).Bullying beyond the schoolyard: Preventing and responding to cyber-bullying. Thousand Oaks, CA: Corwin Press.

3) Joseph, J. (2018). Cyber bullying awareness worldwide 2018, by country. https://www.statista.com/statistics/293192/cyber-bullying-awareness-in-select-countries-worldwide/

4) Lefler, N.L \& Cohen, M.D (2014). Comparing cyber bullying and school bullying among school students: prevalence, gender, and grade level differences. Social Psychology of Education 18(1).

5) Maheshwari, R. (2018). Online Study and Internet Addiction. Onlinespend.com. Scroll.in. retrieved from https://scroll.in/article/956085/in-one-year-alone-cyberbullying-of-indian-women-and-teenagers-rose-by-36

6) Noret, N., \& Rivers, I. (2006). The prevalence of bullying by text message or email: Results of a four year study. Poster presented at British Psychological Society Annual Conference, Cardiff, April.

7) Pempek, T. A., Yermolayeva, Y. A., \& Calvert, S. L. (2009). College students' social networking experiences on Facebook. Journal of applied developmental psychology, 30(3), 227-238.

8) Raskauskas, J., \& Stoltz, A.D. (2007). Involvement in traditional and electronic bullying among adolescents. Developmental Psychology, 43, 564- 575.

9) Smith, P.K., Mahdavi, J., Carvalho, M., Fisher, S., Russell, S. \& tippet, N. (2008). Cyberbullying: its nature and impact in secondary school pupils. Journal of Child Psychology and Psychiatry. Volume 49, Issue 4 p. 376-385. 